\title{
Study on the Reform and Development of College English Teaching in the Age of "Internet +"
}

\section{Li Ying}

School of Foreign Languages, Hubei Engineering University, Xiaogan, Hubei,432000

Keywords: "Internet +", college English teaching, reform, development

\begin{abstract}
The so-called "Internet $+"$ refers to the new format of Internet development under Innovation 2.0 and is a further practical result of Internet thinking. With the development of time, the connotation of "Internet + " is no longer confined to this point. It emphasizes the tremendous change brought by the technology of Internet to people's production and life style. In the new era, Educators have put forward higher challenges and provided more opportunities for the development of education in our country. Therefore, in order to explore the reform of college English teaching in the era of "Internet +", it will play a more promoting role in the development of college English teaching. This article explores the reform and development of college English teaching under the background of "Internet +".
\end{abstract}

\section{Introduction}

With the development of all kinds of scientific and technological means in our country, new teaching methods in the field of education are more and more diversified. However, the micro-class, flip class and large-scale open network course MOOC) and other forms of teaching has also become the current trend of college English teaching reform. On the one hand, the development of this computing technology and internet technology poses a great challenge to the traditional English teaching model and teaching concept, on the other hand, it also provides many opportunities for the innovation and development of college English teaching. Therefore, in the new period of development, we should pay more attention to the application of computer technology and Internet technology in college English teaching in view of the compression of college English teaching credits and hours, and make college English teaching more diversified and more aroused Students enthusiasm for learning, and to promote the improvement of teaching quality.

\section{2. "Internet +" era of college English teaching under the background of the challenge}

The concept of "Internet +", in more general terms, refers to the integration and development of the Internet with various traditional industries. The effect of this development is not limited to "1+ $1=2$ " but requires that all traditional industries with the blessing of the Internet, a breakthrough has been made to create a new ecological development. Under the background of "Internet +", college English teaching is required to be more universal and mobile. Both of these features require college English teaching to be well used at some computer terminals and allow students to access the Internet from anytime, anywhere through computer terminals. "Internet +" requires college English learners to learn English through computer terminals and to break the limitation of time and space brought by traditional English teaching, and require teachers to play a leading role in the college English classroom that is more in line with the times.

\subsection{The traditional teaching mode.}

The most direct impact of the "Internet +" era on college English teaching belongs to the huge impact on the traditional teaching mode. The traditional college English teaching model stays on the blackboard and chalk. In the process of teaching, teachers are still the main body. The "spoon-feeding" education is adopted. The main goal is to improve student's academic performance. In the "Internet +" era, multimedia equipment has a strong application in college English teaching, 
teaching content has also been further enriched. For example, mobile phones, computers and other intelligent devices can become one of the important means of college English learning, which makes the traditional teaching model of college English teaching has undergone tremendous changes. In addition, the new teaching model also requires students to pass from passive acceptance of knowledge to take the initiative to absorb knowledge, that is, to complete the conversion from the receiver to the subject.

\subsection{Traditional learning concepts.}

As a few years ago our country exam-oriented education in our country set off an unhealthy trend of education, which led to the concept of student learning has been affected, the vast majority of students think the main purpose of learning is to deal with the exam, this concept is clearly wrong. With the advent of the "Internet +" era, there should be more changes in student's learning concepts, from passive learning to taking the initiative to absorb knowledge, and to understand that the purpose of learning is to enrich their own connotations rather than to deal with examinations.

\subsection{Traditional teacher's accomplishments.}

Traditional teacher literacy requires teachers to do their utmost to disseminate knowledge to every student and to ensure that every student absorbs knowledge well and applies that knowledge to exams. Under the era of "Internet +", teachers should pay more attention to cultivating their own qualities, and should require themselves to be in line with the times and know more about science and technology. In addition, teachers also need to change their own teaching concepts, we must instill in students the concept of knowledge into guiding students to generate interest in learning, and then take the initiative to learn.

\section{Using a wide range of teaching methods to enrich college English teaching}

Under the era of "Internet +", college English teaching already has more teaching modes to enrich its connotation. For example, MOOC, flip classroom, micro-class is all important teaching modes of college English teaching at present, which is a combination of English and the Internet.

1) MOOC. MOOC's curriculum features include diversified tool resources, easy-to-use courses, extensive course enrollment and strong curriculum participation autonomy. These features enable college students to have higher learning efficiency in their English learning process and pass the self- Autonomy to complete the course content.

2) Turn over the classroom is a kind of classroom subversion of the traditional English teaching mode, which requires students to complete the pre-learning and learning through pre-learning, and in the classroom through some teaching methods to complete the consolidation and deepening of knowledge.

3) Microcosm is a way to present fragmented learning content through classroom videos, which in turn enables students to embrace the core knowledge content of these classes and then consolidate the teaching of this knowledge through exercises.

\section{The establishment of multiple mixed teaching mode}

According to the characteristics of the above three English teaching modes, these three kinds of teaching modes can also be arbitrarily combined to establish a multi-mixed teaching mode or combine some popular computer technologies / Internet technologies to reform college English, so as to improve teaching efficiency and teaching quality.

1) MOOC and flip classroom combination of multiple mixed teaching mode. According to these two characteristics of MOOC, schools can develop teaching resources that are more suitable for our students to learn English based on the original MOOC resources. This kind of teaching resource development can be started from two aspects. One is finding the resources suitable for our English teaching from the existing MOOC resources; on the other hand, the MOOC resources can be researched and produced by the school teachers to realize the reasonable teaching. MOOC and flip 
classroom teaching mode can MOOC teaching resources as the core, require students to MOOC teaching resources before the start of the classroom to understand the classroom content, self-learning classroom knowledge. On this basis, the classroom into question time for students to answer questions. In this way, the most intuitive way is to maximize the quality of teaching MOOC resources to enrich the way students learn and learn, followed by the teaching efficiency can be improved, each student has been through MOOC resources before class this section to learn this section Class knowledge, you can keep up with the teacher's ideas, participate in the class and have good performance, to achieve the advantages of both the MOOC and flip classroom college English teaching complement each other.

2) Multi-mix teaching mode combining micro-class with flip class. The main characteristics of micro-class is the teaching resource content is brief and clear, teaching efficiency, for repeated viewing, but micro-class also has some weaknesses, which is due to teaching resources is too short lead to students in the course of knowledge transfer is difficult, and for some understanding Less capable students, micro-class teaching efficiency after all, difficult to reap the good quality of teaching. According to the characteristics of micro-class, combining it with the flip-class teaching mode can effectively alleviate the situation that some micro-class teaching brings is not conducive to some students to understand the absorption. Micro-class resources include fragmented key knowledge, which is the core of English teaching, before the class, students use micro-class resources first of these key knowledge of the preview, you can use micro-class resources in the exercise to test their own micro-class learning result. On the other side of the courseware, teachers should timely review the students' practice results and record the problems of grammatical usage / improper use of words, so as to find out the similarities that students can make mistakes. After the formal teaching is started, teachers can ask the students if there are any doubts about the students before answering questions about the students. At the end of the exhibition, students can easily explain the mistakes and summarize the main points. In view of some of these points, teachers can also awaken the students' knowledge transfer so that students can better absorb and understand this knowledge.

3) WeChat English learning platform. With the continuous development of information technology and computer technology, smart phones have become the communication tools for all college students nowadays. However, today's smart phone functions are not well utilized by undergraduates, the purpose of students to use mobile phones from the initial communication and exchange into a play games, watching novels. In response to this situation, it is necessary to improve college students' Smartphone use patterns and make Smartphone a tool for students to learn and communicate with. Such as WeChat this software is nowadays more popular social software, which in addition to chat capabilities, but also includes the public number, circle of friends and other functions, easy to view anytime, anywhere, and easy to operate, is currently the most important means of communication one. Therefore, today's English teaching can completely combine with the new chatting software such as WeChat, such as developing a public English number for the school or an English learning group. On the one hand, this combination of methods allows college students to feel that the study of College English can be in line with the times, and on the other hand, provides more convenient modes for college students to learn English.

4) Internet English teaching platform. Now that the Internet has become ubiquitous in people's lives, the reform of college English teaching can be based on the Internet teaching reform. For example, recommending some English learning software to students or setting up an Internet English learning platform within the school are all effective ways to reform the college English teaching model through Internet. Internet contains a wealth of teaching resources, therefore, Internet English teaching more tailor-made features. In teaching materials, it can be divided into three stages: foundation, advanced and development. Then students choose their own teaching materials that suit their level of English and enhance their English proficiency.

\section{5. "Internet +" era of college English teaching example}

1) In order to improve the quality of English teaching, a university proposes a new English 
teaching method based on the background of today's "Internet +" - to develop an English learning exchange platform based on WeChat's public platform functions and group functions. The school first applied for the creation of a WeChat public account for the release of teaching resources within the school. After all the teaching resources were uploaded, each student was required to pay attention to this English language learning public number. Regular public uploads of resources related to English courses in the same period provide students with the opportunity to consolidate their knowledge of the classroom and also set up an opinion forum on the public account for students to timely report their problems with the use of public numbers such as English resources Too few public content and course content does not fit, etc., and in response to these circumstances in a timely manner to design a solution. The school also for different students English level to create a different English learning groups, and require students to choose according to their own English and English learning objectives to join different groups, each group of schools are assigned 2 to 3 foreign teachers responsible for the management, communication within the group is fully using English. After the two policies were officially opened, the quality of English teaching in the school has been significantly improved and students' interests in learning English have also been stimulated.

2) A college English teacher discovers that with the popularization of Smartphone, the efficiency of English teaching is getting lower and higher. Many students play Smartphone and plaything in the English classroom. In response to this phenomenon, the teacher thought hard and eventually decided to adopt the new English teaching mode of "Micro Class + Flip Classroom" so that students can make full use of the smart phones in their hands and study the contents of the class before the class through the corresponding software practice feedback to teachers about learning, then by the teacher to practice problems in student collation to identify the students in the application of the problems and to summarize. After adopting this teaching mode, the Smartphone in the students 'hands are mostly used in English learning, and the English teaching efficiency in this class has been greatly improved, and the students' English learning level has also been significantly improved.

\section{Conclusion}

In summary, based on the "Internet +" era background, college English teaching should be combined with the current status of Internet technology development reform, such as micro-class, MOOC, flip class or WeChat interactive English interactive development platform and so on are the effective reform of English teaching direction. Through the application of these teaching methods, while ensuring the integration of English teaching and the times, it can effectively improve the teaching efficiency and teaching quality so as to realize the maximum benefit of the reform and development of college English teaching.

\section{References}

[1] Li Yan, Luo Yonghui. Research on the Reform and Development of College English Teaching in the Age of "Internet Plus" [J]. English Place, 2017, (10): 137-138.

[2] Lian Hua. Exploring the Teaching Reform of College English Writing in the Internet Age[J]. Think Tank Times, 2017, (09): 236-237.

[3] Zhao Yun. Research on the Reform of College English Teaching in the Age of "Internet +" [J]. Journal of Jilin Radio \& TV University, 2016, (12): 146-147.

[4] Liu Li. Study on the Development Strategies of College English Teaching under the Age of "Internet +" [J]. Shanxi Agricultural University, 2016, (13): 123-124.

[5] Sun Huali. College English Classroom Teaching and Research in the Internet + Age[J]. Journal of Education, 2016,3 (30): 182-183 + 187.

[6] Wang Hongxia. Practice and Achievement of College English Teaching Reform under the Background of "Internet +" [J]. English Square, 2016, (08): 115-116. 